\title{
Heavy Metal Content On Sea Biota And Water At Estuary Region In East Coast South Kalimantan
}

\author{
Muhammad Zaini ${ }^{1}$; Bunda Halang; Glori Merkristivita; Leyla Magfirah Alam \\ Lambung Mangkurat University
}

\begin{abstract}
Coal mining activity produces pollutant which is the coal dusts with heavy metals content. If the dusts mixed into the water, it will cause water pollution. Heavy metals like $\mathrm{Pb}, \mathrm{Zn}, \mathrm{Cu}, \mathrm{Cr}$ needed by the living organisms, but if it exceeds the threshold, it will give negative impacts to the organism. Sea biota like mangrove snail (Telescopium telescopium) and mangrove crab (Scylla serrata) can be used as bio-indicators. This descriptive study aimed to determine the heavy metals content on sea bioata. Assays of Pb and $\mathrm{Zn}$ did on mangrove snail and assay of $\mathrm{Cu}$ and $\mathrm{Cr}$ did on mangrove crab. The heavy metals content in water performed as a comparison. There are three locations for sampling based on mangrove vegetation density which are high density, medium density, and low density. Heavy metals content test was done using Inductively Coupled Plasma (ICP) tool. Water quality standard based on South Kalimantan's governor regulation (No. 5) 2007, and heavy metals content on sea biota based on Indonesia National Agency of Drug and Food Control (Balai POM) No 03725/B/SK/VII/1989. Specific for Cr based on Food and Drugs Administration (FDA). The results showed Cu accumulated over the threshold on mangrove crab in low density mangrove vegetation. Heavy metals content of $\mathrm{Pb}, \mathrm{Zn}$, and $\mathrm{Cr}$ on sea biota below the threshold. Heavy metals content on water also below the threshold. The study was conducted in physical environments that can be tolerated by sea biota.
\end{abstract}

Keywords: heavy metals, sea biota, mangrove snail, mangrove crab, coal stockpile

\section{Introduction}

Human can survive because human can adapt theirself to nature (Soemarwoto, 2003). Wardhana (2004) stated that human can use any science inventories to exploit the environment maximally, and often causes disruption of the environmental balance. Human explore coal to take advantage the environment, as well as give a damaging impact on the environment.

The east coast of Kalimantan since early 90s became the coal temporary collection point (stockpile) before being exported. This place scattered near the river estuary that directly relate to Makassar's straits. Coal mining is not only profitable, but also result disadvantages. This thing happen if the management goes bad, it will cause critical land on the former mining area, decreasing water table, pollution, and the emergence of social insecurity.

Coal dust pollution trigger a change in a community of organisms, even lead to changes the relationship between species (Mukono, 2010). Sembel (2015) stated that heavy metals which pollute the marine environment will accumulate in aquatic biota. One of stockpile example located in Asam-Asam's estuary region, district of Tanah Laut.

Flakes and coal dust that contact directly with the water may cause pollution. Ruch et. al. (1974) as quoted by IARC (1997) stated coal contains $\mathrm{Pb}$ (4-218 ppm), Zn (6-5350 ppm), Cu (5-61 ppm) and Cr (4-54 ppm). Metal-containing coal dust will settle in the water and potentially become a contaminant if it exceeds the threshold.

Estuary region in east coast Kalimantan Island are habitat for sea biota (plants and animals), Houbrick (1991) explained mangrove snail has habitat in mangrove forest. This Gastropod has slow mobility, habitat in waterbed, and has detritus dietary pattern or feeding feeder. (Susanti et. al., 2008, in Rahmawati, 2014). Mangrove crab is another aquatic biota that also has important role in the absorption of heavy metals. Mangrove snail and mangrove crab with their uniqueness used as indicators of water pollution.

According to Effendi (2003) toxic pollutants resulting in impaired on aquatic biota such as morphological disturbances, behavior disturbances, and even death. Mud crabs consumed by the local community as a source of protein that has a major contribution in the inclusion of $\mathrm{Cu}$ and $\mathrm{Cr}$ into the human body. Both of these metals come into the crab's body in two ways, through the food chain where small animals are exposed to heavy metals eaten by the mangrove crab and the digestion process which flowed to the rest of the body.

$\mathrm{Cu}$ metal itself is an essential metal required by mangrove crabs and humans. In humans $\mathrm{Cu}$ needed to maintain a healthy body. While in the mangrove crab according to Mohadi, et. al. (2007) Cu-protein complex is

\footnotetext{
${ }^{1}$ Biology Education Department FKIP Unlam Banjarmasin; muhammadzaini@unlam.ac.id

DOI: 10.9790/2402-1009024851 $\quad$ www.iosrjournals.org $\quad 48 \mid$ Page
}


part of a Hemocyanin protein used as a carrier of oxygen on a number of invertebrates such as mangrove crab. Furthermore, $\mathrm{Cu}$ is the largest metal element in the human body.

$\mathrm{Cr}$ is a type of heavy metals that are harmful to the human body and it's not an essential metal. According Widowati, et. al., (2008) Cr (III) on the human body is needed to metabolize the insulin hormones and control blood glucose levels.

\section{Method}

This descriptive study was conducted over five months (August-December 2015) in Asam-Asam's estuary region, district of Tanah Laut. Data collected through observation, metal content test on meat samples of mangrove snail and mangrove crab in the laboratory using a tool named Inductively Coupled Plasma (ICP).

Mangrove snail and mangrove crabs obtained from their habitat at the sample points based on the mangrove vegetation density (high density, medium and low). Water as a comparison sample obtained from the water in the estuary. The tools that used for this study are nets / sack, cool box, hammer, label paper, ruler, timber or small shovel, analytical balance, plastic clips, and camera. The tools that used for testing the water on this study are Kemmerer water sampler, measuring cups, bottles, $\mathrm{pH}$ meter, thermometer, stopwatch, flow ball, jerigen (a container with a lid to hold waters), sechi disk, cool box, camera, pipette, and ICP.

Sampling the mangrove snail was done through 1) determine the water sampling areas and mangrove snails, 2) set the sampling point, 3) explore the mangrove mud to take the snail, and 4) storing in and preserved in a cool box. Sampling the mangrove crab was done by 1) set a trap, 2) release the mangrove crabs that caught on the trap 3) storing in a bucket, 4) make the crab dead, 5) separating the crabmeat, 6) wrapped with plastic and preserved in a cool box, water sampling is done using Kemmerer Water Samplers, and sterilized with a drop of $\mathrm{H} 2 \mathrm{SO} 4$ solution,.

The test was done in Health Laboratory Province South Kalimantan. The study results data based on 1) POM Directorate General' decree No. 03725/SK/VII/1989. 2) FDA Journal about maximum limits of heavy metal pollution on the crab meats. 3) Water quality standard based on South Kalimantan's governor regulation (No. 5) 2007.

\section{Result}

The analysis results of heavy metal content on sea biota presented at Table 1.

Table 1. Heavy Metal Content on Sea Biota.

\begin{tabular}{|c|c|c|c|c|}
\hline Heavy Metals Type & \multirow{2}{*}{ Sea Biota } & \multicolumn{3}{|c|}{ Level of Heavy Metals (mg/Kg) } \\
\cline { 3 - 5 } & & I & II & III \\
\hline $\mathrm{Pb}$ & Mangrove Snail & $<0,10$ & 0,1802 & 0,5216 \\
\hline $\mathrm{Zn}$ & Mangrove Snail & 11,9761 & 11,9761 & 10,1078 \\
\hline $\mathrm{Cu}$ & Mangrove Crab & 12,5446 & 14,9657 & 22,6619 \\
\hline $\mathrm{Cr}$ & Mangrove Crab & 0,7129 & 0,7255 & 0,6905 \\
\hline
\end{tabular}

Information: $\mathrm{I}$ = High mangrove vegetation/estuary region, II = Medium mangrove vegetation /settlement region, III = Low mangrove vegetation/Nipa palms.

Threshold: $\mathrm{Pb}=2.000$ ppb, $\mathrm{Cu}=20.000$ ppb (Anon., 1989). $\mathrm{Zn}=100 \mathrm{mg} / \mathrm{kg}$ (Hasti, 2013, $\mathrm{Cr}=2,5 \mathrm{mg} / \mathrm{kg}$ (Budiati, 2014).

Table 1 show heavy metals $\mathrm{Pb}, \mathrm{Zn}$, and $\mathrm{Cr}$ content are below the threshold which has been set. $\mathrm{Cu}$ content in station III exceed the threshold, the area with low mangrove vegetation area. Heavy metal that contained on water presented on Table 2. Content of Heavy metals ( $\mathrm{Pb}, \mathrm{Zn}, \mathrm{Cu}$, and $\mathrm{Cr}$ ) on the table 2 shows the result lower than the threshold that has been set. The results showed $\mathrm{Cu}$ exceeded the threshold on the mud crabs in the low density mangrove vegetation. Heavy metal content in the water also shows below the threshold. Research was conducted in physical environments that are measured and can be tolerated by sea biota such as in Table 3 .

Table 2. Content of Heavy Metals in Water Samples

\begin{tabular}{|c|c|c|c|c|}
\hline \multirow{2}{*}{ Heavy Metals Type } & \multicolumn{3}{|c|}{ Level of Heavy Metals (mg/L) } & \multirow{2}{*}{$\begin{array}{c}\text { Normal Range } \\
\text { (mg/L) }\end{array}$} \\
\cline { 2 - 4 } & I & II & III & $<0,1$ \\
\hline $\mathrm{Pb}$ & $<0,0069$ & $<0,0069$ & $<0,0069$ & $<2$ \\
\hline $\mathrm{Zn}$ & 0,0350 & 0,2796 & 0,0213 & $<2$ \\
\hline $\mathrm{Cu}$ & 0,0099 & 0,0108 & $<0,0093$ & $<0,5$ \\
\hline $\mathrm{Cr}$ & 0,0251 & 0,0151 & 0,0234 & \\
\hline
\end{tabular}


Informastion: I = High Mangrove Vegetation/estuary, II = Medium mangrove vegetation /settlement region, III = Low mangrove vegetation/Nipa palms.

Table 3. Environment Parameters

\begin{tabular}{|l|c|c|c|c|c|}
\hline \multirow{2}{*}{ Parameters } & \multirow{2}{*}{ Unit } & \multicolumn{3}{c|}{ Sampling Points } & \multirow{2}{*}{ Normal Range } \\
\cline { 3 - 5 } & & I & II & III & \\
\hline Water temperature & ${ }^{\circ} \mathrm{C}$ & 28 & 30 & 34 & $<38$ \\
\hline Acidity degree $(\mathrm{pH})$ & - & 7,1 & 7,5 & 7,6 & $6-9$ \\
\hline Water brightness & $\mathrm{cm}$ & 28,2 & 17,6 & 22,7 & - \\
\hline Flow velocity & $\mathrm{m} / \mathrm{s}$ & 0,054 & 0,066 & 0,051 & - \\
\hline BOD $_{5}$ & $\mathrm{mg} / \mathrm{L}$ & 12,80 & 12,10 & 8,60 & $<100$ \\
\hline COD & $\mathrm{mg} / \mathrm{L}$ & 32,19 & 30,36 & 21,66 & - \\
\hline Salinity & $\mathrm{ppm}$ & - & - & - & $500-30.000$ \\
\hline
\end{tabular}

Informastion: I = High Mangrove Vegetation/estuary, II = Medium mangrove vegetation /settlement region, III = Low mangrove vegetation/Nipa palms.

\section{Discussion}

$\mathrm{Zn}$ content on the sea biota is below the set threshold, it is in line with the results of previous studies ( Hasti , 2013 ; Rochyatun et al. , 2006). She found the Zn content is detected on an anchovy with the value is still below the maximum limit of $\mathrm{Zn}$ concentrations that allowed on the sea biota muscles as big as $100 \mathrm{mg} / \mathrm{kg}$ dry weight. $\mathrm{Zn}$ content in the water is below the threshold, it is different with previous findings ( Houbrick, 1991). Low tide causes the metal ions accumulate so that the metal content in the water is high. The more frequent the mangrove snail doing this activity, the higher the concentration of metal that accumulates in the flesh.

$\mathrm{Zn}$ content on the water below the set threshold, it is supported with another studies (Hasti, 2013). The low $\mathrm{Zn}$ content in the water caused by $\mathrm{Zn}$ metal concentration in the water can settle on the bottom of the water (sediment), so that the metal content in the sediment dissolved in the water that causing high metal concentration in the water. Water in Asam-Asam estuary is a river estuary that containing silt, it can be used as a reason for the low $\mathrm{Zn}$ content in the water.

$\mathrm{The} \mathrm{Pb}$ content on the sea biota also below the threshold, it's in the line with previous studies (Palar, 1994), Pb sediment's formation on brackish water are very low, but there're still possibilities that the metal will also settle on the bottom of the water and continue to increase over time. $\mathrm{Pb}$ will go into the air layer in previously, crystallize, and then brought by rain and pollute water and soil. The small metal particle size, ease the movement of $\mathrm{Pb}$ metal crystal to elsewhere.

$\mathrm{Pb}$ content in the water is show below the threshold. The low $\mathrm{Pb}$ content at the water may be related with the mangrove characteristic that can accumulate metal. According to Kariada (2014) mangrove plants have tendency to accumulate heavy metals in the surrounding areas, but the ability to accumulate different for each species. According to Slamet (2004) the absorption process can be happen through the plants organs like roots, leaves, and stomata. Besides relying on the absorption of organic compound in the water, $\mathrm{Pb}$ content also be influenced by the presence of the vegetations in surrounding.

The $\mathrm{Cr}$ content on sea biota also below the set threshold, it's different from the studies that have been reported before (Suprapti, 2008). She found that $\mathrm{Cr}$ content on the sediment and Mussels Blood (Anadara granosa) found as big as 0,1278-0,1617 ppm, means has exceeded a specified threshold (0.0500 ppm). According to Corr ea Junior et. al., (2005) in Pinheiro, et. al., (2012) the Cr metal go into the mangrove crab body through the gills and after that go into the body flow and go to the claws until stop at hepatopancreas, or change into, from the gills to the hepatopancreas and then go into the claws. Even in this research, $\mathrm{the} \mathrm{Cr}$ content is below the threshold, consumers can avoid the $\mathrm{Cr}$ poisoning, because they just eat the meat crab only.

The $\mathrm{Cu}$ content on mangrove crab exceeded the threshold, especially at mangrove vegetation with low density. This is different with the previous studies (Priyanto, et.al., 2008). They found that $\mathrm{Cu}$ on the fish still below the allowed threshold. $\mathrm{Cu}$ content in the water is below the threshold, this is also different with the previous studies (Priyanto, et.al., 2008). They did the study in Cirata Resevoir, different with the studies in Asam-Asam River Estuary as it is shallow water.

The mangrove plants can absorp heavy metals, go into the tissue through the roots (Yanti, 2009). If the mangrove density become higher, then the mangrove ability also becomes greater to absorp heavy metals. Furthermore, the heavy metals that already collected will distributed to the all parts of the plant (Siburian, 2015). This study was conducted in Asam-Asam River Estuary with a weak flow. According to Sanusi (2005) in Priansyah (2012) argue that distribution patterns of metal concentration is generally followed the pattern of the flow. 
The study result shows that $\mathrm{Cu}$ accumulated exceed the threshold on mangrove crabs in mangrove vegetation with low density. $\mathrm{Pb}, \mathrm{Zn}$, and $\mathrm{Cr}$ content on sea biota are below the threshold. Heavy metals content in the water also below the threshold. Research was conducted in physical environments that can be tolerated by sea biotas.

\section{Bibliography}

[1]. Direktur Jenderal Pengawasan Obat dan Makanan Nomor: 03725/B/Sk/VII/89 tentang Batas Maksimum Cemaran Logam dalam Makanan

[2]. Effendi, H. 2003. Telaah Kualitas Air. Yogyakarta: Kanisius.

[3]. Hasti, W. 2013. Kandungan Logam Berat pada Air, Sedimen dan Plankton di Daerah Penambangan Masyarakat Desa Batu Belubang Kabupaten Bangka Tengah. Semarang: Universitas Diponegoro.

[4]. Houbrick, R. S. 1991. Systematic Review andFunctional Morphology ofThe Mangrove Snails Terebralia and Telescopium (Potamididae; Prosobranchia). 1991. USA: Malacologia.

[5]. IARC. 1997. IARC Monographs on the Evaluation of Carcinogenic Risk to Human. 68.

[6]. Kariada, Nana, T.M; Irsadi, A. 2014. Peranan Mangrove sebagai Biofilter Peencemaran Air Wilayah Tambak Bandeng Tapak, Semarang. Jurnal Manusia dan Lingkungan 21(2).

[7]. Mukono, H, J. 2010. Toksikologi Lingkungan. Surabaya: Airlangga University Press.

[8]. Mohadi, R; Nurlisa H; Melany N.R. 2007. Preparasi dan Karakterisasi Kompleks Kitosan Hidrogel-Tembaga (II). Palembang: Universitas Sriwijaya.

[9]. Nugroho, A; Wahyono; H; Fatimah, S. 2005. Pengembangan Metode Analisis Menggunakan Alat ICP AES plasma 40 untuk Penentuan unsur As dan Sb. Hasil-hasil penelitian EBN tahun 2005.

[10]. Palar, H. 1994. Pencemaran dan Toksikologi Logam Berat. Jakarta: Rineka Cipta. Bogor: Institut Pertanian Bogor.

[11]. Pinheiro, M; Antonio A.; Pablo P.G. e Silva. Luis F. de Almeida D.. Alaor A. A.; Flavia P.Z. 2012. Accumulation of Six Metals in The Mangrove Crab Ucides cordatus (Crustacea: Ucididae) and Its Food Source, The Red Mangrove Rhizophora mangle (Angiosperma: Rhizophoraceae). Ecotoxicology and Enviromental Sagety 81 pp.114-121.

[12]. Priyanto, N.; Dwiyitno, D. ; Ariyani, F. 2008. Kandungan Logam Berat (Hg, Pb, Cd, dan Cu) pada Ikan, Air, dan Sedimen di Waduk Cirata, Jawa Barat. Jurnal Pascapanen dan Bioteknologi Kelautan dan Perikanan 3(1).

[13]. Priansyah, Z; Amin, B.; Nedi, S. 2012. The Content of Heavy Metals Pb, Cu, Zn, on Several Types of Molluscs in Waters Concong Luar Indragiri Hilir district of Riau province. Pekanbaru: Universitas Riau.

[14]. Rahmawati, R. 2014. Analisis Tingkat Pencemaran Berdasarkan Indeks Keragaman Populasi Gastropoda di Bagian Tengah Sungai Gajahwong dan Kali Kuning Yogyakarta. Yogyakarta: UIN Sunan Kalijaga.

[15]. Rochyatun, E; Kaisupy, Muhammad T.; Rozak, A. 2006. Distribusi Logam Berat dalam Air dan Sedimen di Perairan Muara Sungai Cisadane. MAKARA, SAINS, 10(1) pp:35-40

[16]. Sembel, D.T. 2015. Toksikologi Lingkungan. Yogyakarta: Andi.

[17]. Siburian, F. 2015. Akumulasi Logam Berat (Cu dan Pb) pada Rhizophora stylosa Berdasarkan Tingkat Pacang Pohon. Medan: Universitas Sumatera Utara.

[18]. Slamet, J.S. 2004. Kesehatan lingkungan. Yogyakarta: Gadjah Mada University Press.

[19]. Soemarwoto, O. 2003. Analisis Mengenai Dampak Lingkungan. Yogyakarta: Gadjah Mada University Press.

[20]. Suprapti, N.H. 2008. Kandungan Chromium pada Perairan, Sedimen dan Kerang Darah (Anadara granosa) di Wilayah Pantai Sekitar Muara Sungai Sayung Desa Morosari Kabupaten Demak, Jawa Tengah. BIOMA, 10(2) pp.: 36-40

[21]. Yanti, G.P. 2009. Akumulasi Logam Berat Tembaga (Cu) dan Timbal (Pb) pada Pohon Avicennia marina di Hutan Mangrove. Medan: Universitas Sumatera Utara.

[22]. Wardhana, W.A. 2004. Dampak Pencemaran Lingkungan (Edisi Revisi). Yogyakarta: Andi.

[23]. Widowati; Wahyu; Sastiono; Astiana; Jusuf, R.R. 2008. Efek Toksik Logam. Yogyakarta: Andi. 